\title{
Rural Immigration in Turkey and Agricultural Problems
}

\author{
Assist. Prof. Dr. Ertugrul Guresci \\ Ahi Evran University, Faculty of Economics and Administrative Sciences
}

\begin{abstract}
In developing countries like Turkey, it is feasible to argue that the reasons and consequences of rural immigration echo a significant portion of the common financial and social problems pertaining to that particular country. In Turkey the emergence of rural immigration corresponds to years following the 1950s particularly and in the aftermath of 1980s it has been elevated to the status of a critical national problem. It has been reported that the reason accounting for this status is predominantly related to the problems introduced by rural immigrants in the cities. Once analyzed from this perspective it is easy to claim that rural immigration is regarded as a problem mostly in the eyes of urban dwellers. The failure to treat the problem within the scope of rural population and agricultural sector in Turkey is likely to be a missing part in the relevant studies focusing on this particular issue. Driven by this motive, present study aims to analyze how and to what extent rural immigration can affect agricultural problems in Turkey. To draw a conclusion on this inquiry, relevant literature studies and statistical data have been screened.
\end{abstract}

Keywords: Immigration, rural immigration, agriculture JEL Code: R11, R23

\section{Introduction}

Generally speaking, the regions outside the borders of urban lands are described as rural regions. Locations within these regions are, according to Turkish Statistical Institute (TSI), settlements with smaller than 20 000dwellers (Olhan 2011). Rural regions are settlements of which general economical and structure depends heavily on agriculture. Indeed these regions are, compared to urban regions, locations where economic and social life develops slowly and the population is relatively more conservative (Tolunay and Akyol 2006).

Rural immigration can be defined as the migration of rural settlers-due to various reasons- from their original habitation to urban regions (Güreşci 2009).Broadly speaking since compared to urban regions rural regions emigrate larger populations; these regions are also described as regions that periodically emigrate.

Rural immigration is explained as the disintegration of rural settlers who abandon agricultural practices. Particularly in the aftermath of Industrial Revolution that was initiated in Britain, an intense wave of labor force immigration from these regions to industrial locations was experienced. To illustrate, while in 1800 there were total 20 cities in Europe with higher than 10000 population, in 1900 the number of cities with such population increased to 150 in Europe and North America. This figure escalated to600 in 1950 and presently the population in most of these cities exceeds millions of people (Güran 2009:150).

Rural immigration has exhibited a rise parallel to the industrialization period in particular and in developing countries basically, this figure has reached to remarkable levels. In Turkey on the other hand in the aftermath of 1950, rural population started to disintegrate evidently and subsequent to the 1980 s an intense wave of rural immigration has been witnessed. Such slow and advanced type of immigrations which was squeezed within a brief period introduced along new financial and social problems in developing states like Turkey (Beauchemin and Bocquier 2003, Güreşci 2011, Karpat 2004,Güreşci 2012a,Schmidbaueret al., 2011,Wosu and Anele 2010,Zhang and Song 2003).

What comes to mind first about rural regions is that the lifestyle and economic structure in these habitats are largely dependent on agriculture. The gravity of agricultural activities of which roots are as ancient as human history is heavy in today's world as well. It is an acknowledged fact that the reason why agriculturewhich provides essential needs of people- today can no longer feed even its own settlers is attributed to the heavy pressure of populations in rural regions.

Rural regions which at the onset of Republic hosted approximately $70 \%$ of entire population started to disintegrate in the course of time. Presently they still contain a wide portion of population though not as much as the past years. The sharing of added-value obtained from existing agricultural structure with this particular population has brought with itself poverty and misery problems for this sectionals well (Güreşci 2010).

Thanks to its geographical location, climate conditions, land structure and vegetation Turkey is a country greatly favorable for agricultural production. However within the framework of this general structure prevailing agricultural problems and intense population in this already-failing structure further bump these travails which become harder to solve by each passing day.

As a consequence of rural immigration the population lives off by agriculture remarkably shrinks and agricultural resources they leave behind are considered to a large extent as waste-resources. Transforming 
existing agricultural resources-lands in particular- into new agricultural production centers and in that way creating extra resources of agricultural income is an important fact that should be focused on. Based on this perspective it has been aimed in current study to seek the ways to establish a problem and solution connection between agricultural problems in Turkey and rural immigration.

\section{Overall Structure of Rural Immigration in Turkey}

In developing countries like Turkey rural immigration is considered to be one of the most salient criteria of economic and social achievements. Generally speaking pulling the ratio of rural population below the level of general population is a desired situation. That is because the shift of economy from agricultural activities in rural parts -key determinant of life- to industry and service sectors of which marginal yield is higher is an approach that is largely supported. Nonetheless perhaps the most significant reason why in Turkey rural immigration is considered as a problem is that shrink in rural population- therefore agricultural population - is experienced too slowly within quite a short time interval. Let us put it this way: the failure of cities to internalize rural immigration that started and remarkably paced in the 1950s and economical and social conflicts introduced with this wave of immigration (Güreşci 2012b; Taşç1 2009) has brought about a set of problems. In Turkey as of year 1927 the ratio of rural population was $75.80 \%$ while in 1950 it plummeted to $70.00 \%$, in 1960 to $68.20 \%$, in 1980 to $56.10 \%$, in 1990 to $41.00 \%$, in 2000 to $35.10 \%$, in 2010 to $23.70 \%$. Presently this ratio is even lower (Wikipedia 2012). From 1927 to 2010 urban population has increased around 94.11\%whileruralpopulation has increased around $40.80 \%$ during the same period. It is possible to claim that the greatest reason accounting for the rise in urban population is the wave of migration from villages to cities. Based on the assumption that increase in urban population is lower than the increase in rural population, it can reasonably be asserted that the most significant determinant of this surge in urban population is immigration from villages to cities. In short, the primary characteristics of rural immigration in Turkey is that it took place in quite a short length of time and not followed a process parallel to industrialization and urbanization(Güreşci 2010).

The fact that rural immigration in Turkey has taken place much faster than normal economic and social changes introduced along a set of city-based problems which are largely analyzed and expressed from an urbanism point of view. It is for sure that the biggest reflection of rural immigration is witnessed in cities where the problem is heavily centered upon (Gürbüz 2007,Güreşci 2011,Sağlam 2006).Nevertheless what should also be kept in mind is that people who have had problems in rural life bring with themselves the very same concerns and also leave many other problems behind. These are the agricultural resource wastes abandoned by immigrants; emotional traumas experienced by relatives and friends and despite decreasing population the public services- which are more costly and less productive - that the state provides for the rest of settlers. High costs of public investments in rural section on one hand triggered the waste of public resources and on the other hand such unproductive investments caused ineffective use of agricultural and human resources in rural regions. This is undoubtedly a reason accounting for the decreased motivation for private investors and entrepreneurs to invest in rural regions. Rural regions with insufficient raw materials and trained labor force face inadequate capital of entrepreneurs thus even a greater backlash is experienced in current structure. As Ayylldı (1992) reports likewise, inevitably, rural regions are entrapped in the poverty which is almost impossible to set free.

In the past certain theoretical approaches have been introduced to explain the causes of rural immigration. However it is possible to argue that such theories have mostly been valid in explaining the process in European states where industrialization took place under normal circumstances. In countries such as Turkey where immigration developed abnormally, these waves of immigration not only had been influenced by economic and social changes but political shifts likewise.

It can be claimed that the reasons of immigration from rural areas to cities can be collectively listed under three headings; repulsive factors, attractive factors and transmitter factors. Repulsive factors of rural lands are factors that are basically related to agricultural problems whereas attractive factors in the city arise from the opportunities provided herein. Transmitter factors can be defined as developments in transportation and communication which enable easy-access to such opportunities (Başel 1998, Bülbül veKöse 2010, Çağlayan 2006,Çelik 2006,GürbüzveKarabulut 2008, Toroğlu 2007).

It is a well-known fact that the most essential cause of rural immigration is agricultural problems encountered by rural dwellers. That is to say that these problems are related to the low-level of agricultural production and agricultural yield in these regions and the rapid absorption of this small income amidst heavily populated settlers. It can be claimed that this sector -far from making any savings but shadowed by risk and ambiguity- has turned into even smaller expectations parallel to the rise in population (Bilsborrow 2002, Ofuoku and Chukwuju 2012, Mere 2007). In Turkey rural immigration can be explained from the points of agricultural problems in rural areas and density of rural population. To sum up in Turkey the two distinctive outcomes of rural immigration are the decrease in rural population and increase in urban population.

In Turkey, insufficiency of data on rural immigration is a great hindrance in demonstrating current status of such type of migrations. TSI's statistics on immigration are consulted as the major source of data; 
however it is a drawback that such statistics are not specified under a heading as rural immigration. It is a positive change that via Address-Based Population Registration System (ABPRS), immigration statistics which were prepared for a period of five years have recently been categorized as one-year statistics (TÜIK 2012a).However the fact that these statistics are city based and Net Immigration Rate (NGO) centered is the reason why immigration from rural lands to urban regions has been ruled out. According to TSI rural population consists of inhabitants living in locations with smaller than 20000 population. Thus towns and villages are also included in the description of rural region, but this is not a plausible approach. ${ }^{1}$ Since 1924-dated Village Law, a lot of water has flowed beneath the bridge and populations there, particularly in Eastern and Black Sea regions, have become excessively depopulated (Mevzuat 2012). Population-based descriptions of village, town and rural region might be administratively appropriate, but incomplete for describing ruralregion since description of a particular region as rural should not be only population-based but related to agricultural dependency of the general economic structure in this region as well. Indeed detecting the weight of agriculture in any region's income, employment and other economic and social indicators and defining the regions where this ratio is higher than a certain level as rural area can be a more appropriate and negotiable approach. In the end establishing rural immigration data in Turkey on a solid surface and periodic receipt of such data can be helpful in preparing the base for relevant scientific studies.

\section{Agricultural Problems in Turkey}

Agriculture dates back as ancient as humanity. The primitive men had lived off hunting and gathering as nomads but due to the changes in living conditions these practices were transformed into settled life in the course of time.

The settled lands are agriculturally more productive regions where basic diet and accommodation needs can be met to a larger extent. It is known that these regions are waterfronts and valleys. Thanks to its rich natural resources Anatolian geography has been one of the locations where agricultural activities were first initiated (Şenel 1982: 40-63,Yeğenağa 2009: 5-8) thus Turkey is established on one of the most ancient civilizations endowed with agricultural riches.

Agricultural activities are significant fields of activity explaining development process of societies. The first steps that Republic of Turkey which inherited a deteriorated and agriculture-based economical substructure from Ottoman Empire took in the field of economy have been in agricultural domain. Abolition of tithe, acceptance of Civil Law and Preservation of Wheat Law are the first revolutions coming to mind. One of the founding principles of new Turkish Republic has been providing an esteemed life for the villagers whom Ataturk elevated to the status of lord of the nation. In the aftermath of Ataturk, global changes- $2^{\text {nd }}$ World War in particular- that took place in the entire world have also been effective in the economic and social structure of Turkey. Parallel to the national defense, agricultural products have mostly been used in meeting the needs of army (Coşkun 2003,Topuz2007).Multi-party regime introduced after 1950 has triggered substantial changes in the economic and social structure of Turkey fueled then by urbanization and industrialization. It is feasible to argue that this transformation has enabled even more liberal steps in the field of economy (Baytal 2007).Subsequent developments and post-1960'splanning-based economy policies have brought along protective policies in agricultural sector. Parallel to the needs, the state has adopted a protective approach towards agricultural sector and sought the ways to backup agriculture via different methods. Towards this end initiatives have been taken to establish state enterprises and plants. Therefore an approach has been taken to promote agriculture-based production. Via foreign expansion policies that flowed after 1980, certain steps have been paced to execute liberal agricultural policies.

It is undoubtedly possible to explain developments in Turkish agriculture from a broader perspective; however it can be asserted that Turkey-EU relations and the effect of this process as a determinant of Turkish agriculture and policies have been important signifiers. It should also be noted that Turkish agriculture has taken technical and legislative harmonization steps to comply with EU Common Agricultural Policy (CAP) (Güreşci ve Atsan 2009, T.C. Gıda Tarım ve Hayvancılık Bakanlığı 2011, Oğuz 2012).

To better illustrate the problems of agricultural sector, it is necessary to put forth the importance of this sector. To detect agricultural problems and solution methods, it should be a better approach to note that the problems pertaining to a significant sector are also grave thus rapid steps need to be taken to solve such problems.

The most significant aspect that makes agricultural sector vital and even strategic is that the products procured from this sector are used to meet essential living needs of people. Agriculture sector meets food requirements of population thus it is closely related to raising healthy generations. Therefore agriculture sector

${ }^{1}$ First article in 442 no 1924 no Village Law: 'Settlings with smaller than two thousand populations are (village), population between two thousand and twenty thousand are (town) and larger than twenty thousand populations are (city). Regardless of population smaller than two thousand any districts, provinces and city centers with a municipal organization are categorized as town...' thus places with more than 20 000 dwellers have been defined as city. 
needs to follow a sustainable production approach in line with the needs that enhance parallel to growing population.

Parallel to its gravity agriculture sector leaves a set of effects by virtue of,

1. The population it withholds,

2. Its contribution to national income,

3. Its contribution to exportation,

4. Its raw-material supply to industry,

5. Its effect to open demands for industrial good,

6. Providing labor force to industrial sector. The betterment and production-increase in agricultural sector shall create positive effects in other sectors which in turn might be effective in enhancing national welfare (Ayyıldız 1992, Karagölgevd, 55-74).

One of the most visible indicators demonstrating the significance of agriculture in Turkey is the population it withholds and its contribution to employment. Relevant data from years 2011-2012 are as given below (TÜiK 2012b).

Table 1. Distribution of rural and urban population in Turkey

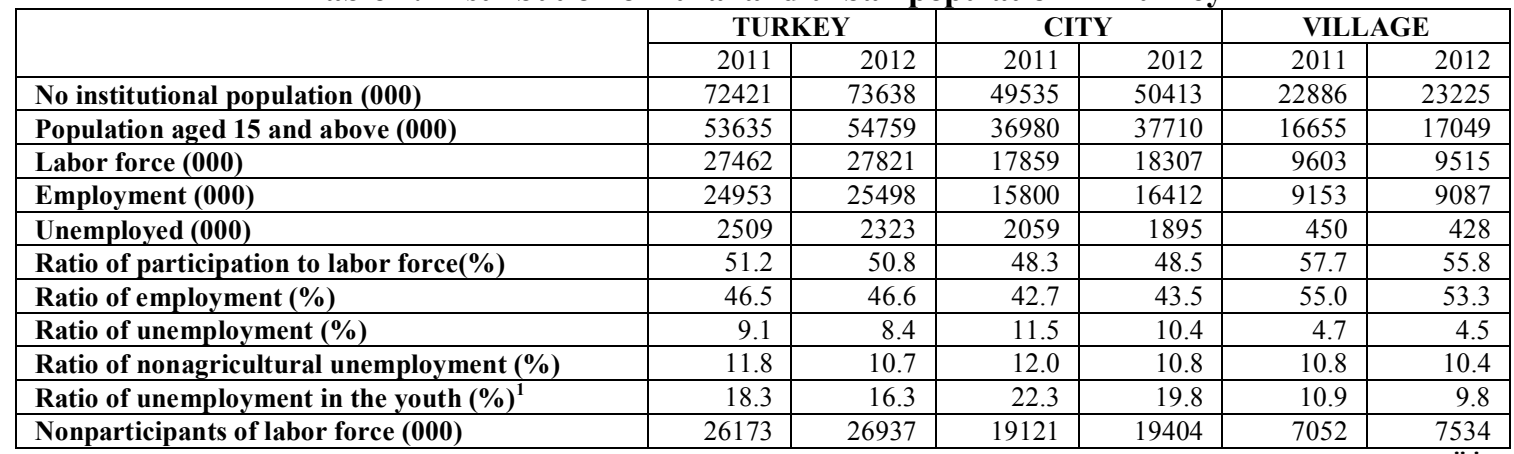

(1)Population between ages 15-24, the figures, due to rounding, may not correctly reflect the total sum (TÜIKK 2012b).

As regards Turkey in year 2012, the fact that of all the labor force in Turkey $53.30 \%$ was employed in rural regions indicates that a majority of population cultivates economic expectations in regions where agriculture is fore grounded. In rural regions, those employed in nonagricultural sectors are still directly or indirectly related to agricultural population. Year 2011-dated Research report released by the Ministry of Finance, Department of Strategy Development has manifested certain data on the agricultural employment of Turkey and some of the developed states. ${ }^{2}$ Accordingly in Turkey, of all the employed population in year 2009, $23.70 \%$ were employed in agriculture. The same report indicates that the same ratio was $1.50 \%$ in the US, $2.40 \%$ in G7 states, $3.80 \%$ in Euro Zone and circa 5.00\% in OECD countries (T.C. Maliye Bakanlı̆ğ 2011).

Despite that in Turkey agricultural population and the share of agriculture in employment gradually slowed down with the oncoming years. Nonetheless this ratio is still remarkably higher in comparison to developed states and groups of states.

It has been detected that in Turkey the approximate share of agriculture in GDP (gross domestic product) as of year 2011 is $9.15 \%$. This ratio has fallen down parallel to the years but it is still remarkably higher in comparison to developed states. Similarly the ratio of industrial growth during the same period has been reported to be $9.0 \%$ (TSI, 2012 main economic indicators). The fact that in 2005 within 27 European Union states the share of agriculture in overall GDP was2, 5\% is a significant indicator demonstrating the difference between years (Uysal and Oktay 2008).

According to foreign trade statistics the share of agriculture, forestry and fishery products within total export is $3.30 \%$. There are many other indicators verifying that agriculture takes a prominent place in Turkey. However the fact that agriculture is so vital in Turkey brings along the problems related to this sector as well. These problems can be listed under main titles as below (Ayyıldız 1992, Bozdağlıoglu 2008, Demirdöğen vd., 2012, Erkan and Tan 2007, Uçak ve Berk 2009, Yilmaz 2006).

1. Technical problems of agriculture: These problems are about whether utilized tools and materials in agricultural production are appropriate or not. To put differently what is the relationship between current

${ }^{2}$ Euro Zoneand OECD datareflecttheyear 2008. 
agricultural structure and capital of Turkey and tools and methods utilized in production? There are two potential answers to this inquiry:

a- $\quad$ Utilized tools and methods are appropriate and adequate.

b- Utilized tools and methods are not appropriate and adequate.

If second choice is selected, tools and methods utilized in Turkish agriculture should absolutely be - within the context of current conditions- reformed by considering their potential effects on production, productivity and quality. Or as a different alternative, agricultural production areas, production pattern and methods applicable to advanced agricultural technology and methods should be designated. Solution to the technical problems of agriculture lies partially on the extent sartorial employee's adopts these methods and techniques. This is on the other hand related to the capacity of agricultural population to procure and utilize such means.

2. Substructure problems of agriculture: Substructure problems of agriculture are particularly visible in Turkey. These problems can be listed under below-given titles:

a. Problems stemming from agricultural population:

-if

-agricultural population density is high,

-agricultural population performs agricultural activities in less developed regions such as villages or towns which are around 40000 in number,

- Major portion of this population has insufficient level of general and professional knowledge level,

-they have a disorganized structure,

b. Problems stemming from organizations: The problems in organizations where agricultural activities are conducted and production factors are harmonized matter greatly in agriculture: In Turkey,fore grounded problems stemming from agricultural organizations are as below:

-organizations are small,

-organizations are fragmented,

-organizations are non-united,

-most organizations are subsistence-dependent, traditional family companies,

-they have substantially loose bonds with the market,

-capital structure is comparatively poor; farm capital is mostly used,

-leaser and partner structuring is underdeveloped,

3. Problems stemming from agricultural lands, structures, animal and plant species: These problems are related to the evidences that a major part of productive agricultural lands in Turkey are crushed by urbanization and in the remaining agricultural lands which are unproductive, agricultural production is problematic. Animal shelters that constitute the most salient factor in agricultural activities are available mostly in villages and they are quite primitively erected. In such shelters when low-fertile animal races are used agricultural productivity and quality fall down even more.

4. Economic problems of agriculture: These are the problems that are the most visibly for grounded in Turkish agriculture. They take up such front seats that agricultural problems are only dealt from this perspective and underlying causes are most of the times ignored. The most significant problem of Turkish agriculture is that income level is low, capital turnover is slow and below expectations for entrepreneurs thus the risk and blurriness in the sector are extremely high. Economic problems of Turkish agriculture are the most general reflections of substructure and technical problems.

The problems concerning Turkish agriculture are increasingly turning into a balls-up growing each new day with its causes and effects. Due to the presence of substructure and technical problems economic problems keep dominance and due to the presence of economic problems technical and substructure problems gain impetus. Agricultural problems in Turkey should be analyzed within this framework. However support policies that aim to solve the vicious circle only through foregrounding market mechanism and prices fail to be successful. That is because supporting the malfunctioning structure would in no way provide solution to agricultural problems and moreover it would even lead to an underestimation of these travails. In Turkish agriculture sector where it is not even possible to detect the length of effects of agricultural subsidies it is motivating to see that there are certain new policies such as agricultural enterprise registration system, farmer registration system, animal registration system, plant passport systems and basin-based agricultural support policies. It should also be taken into account the way European Union solved its agricultural substructure problems via Mansholt Plan and reached its current status. 


\section{The Relationship between Rural Immigration and Agricultural Problems}

It has been previously explained that agricultural problems in Turkey stem from various factors. However human resources in one sector can be not only the cause but also the solution of problems in that particular sector. The problems in any sector can be minimized by qualified sector employees, administrators and planners (Güreşci 2012b). The fact that agricultural sector employees in Turkey are generally classified as villagers brings about the push of social growth and development of this sector into the background or secondary priority. It can be argued that the major source of the problems in Turkish agriculture is connected to dense-population within the sector.

Agriculture sector which is structurally filled with risks and ambiguities already contains a structure where economic developments take place at a comparatively slower pace (Günaydın 2006, Karagolgevd. 2011). Once this structure is accompanied with deficient or misleading policies the problems surrounding the sector increase even higher. In developed countries the fact that the share of agricultural population within general population is small can be regarded as the consequence of long years. That is to say that in these countries agricultural population has gradually plummeted parallel to the industrialization process and reached optimum level presently. In Turkey on the other hand agricultural population has fallen down throughout the years yet this decrease has not taken place in line with industrialization and hence in Turkey rural immigration has been viewed as a problem.

The most visible outcome of rural immigration is that due to the shrinkage in rural population, agricultural population that constituted a significant portion of rural dwellers has also decreased and as a result the ratio of urban population skyrocketed. Based on this assumption it is necessary to acknowledge that there is a connection between rural immigration and agricultural problems and also to detect how this connection can be utilized in solving agricultural problems (Asfaha and Jooste; 2006; Güreşci 2009, Mendola 2006,Peker 2004).The issue should first be analyzed by detecting the problems rural population creates in agriculture. These problems are;

1. High population in agriculture shall directly dwarf already small, fragmented and unorganized enterprises and make them even more fragmented and unorganized. This will in turn accelerate substructure and technical problems in Turkish agriculture which inevitably shall cut down added-value per person. Unless additional measurements are taken, such fragmentation shall bring along new poor people who shall be forced to immigrate to cities to find new settlements.

2. The high agricultural population in Turkey shall block capital accumulation. Thus the capital obtained from this sector which already has slow capital turnover shall be drained once again by the escalating population. In that case it is possible that new poor people shall emerge in agriculture and these people shall consider immigration to city as the ultimate solution.

3. The high agricultural population shall also diminish unit space of agricultural land per animal. Even if improvement practices are made, Turkish husbandry that has low-fertile races shall take benefit from per animal land spaces and diminished lands of meadows and ranges.

4. The high agricultural population blocks the flourishing of alternative agricultural production in lands which in turn shall allocate smaller or even no resources for apiculture, medical and aromatic plant growing, aqua product growing which are amidst alternative agricultural production fields.

5. Parallel to the surge in population density the share of agricultural subsidies allotted for this section shall enhance and in the planning and organization process, certain problems shall be experienced.

6. Education and public extension services for the high agricultural population shall be more difficult both theoretically and financially.

7. The density in agricultural population can also bring about difficulties in organizing.

8. In providing public services to denser population the quantity of personnel and public resources shall be heightened which in turn shall boost up public service costs.

The problems listed above shall not only be reflected on agriculture but on the other sections of society likewise which might inevitably turn agricultural problems into national problems in Turkey.

However it would not be reasonable to argue that all agricultural problems in Turkey stem from dense population. It is necessary to remind that these problems also stem from policy failures or inadequacies. The solution of current agricultural problems may also be related to dense population in Turkey which might also constitute the base for another matter of dispute. Nonetheless surplus in agricultural population density should not be gradually solved via agricultural problems alone but coordinately with urbanization and industrialization policies.

Rural immigration is the most visible process in the slump of agricultural population in Turkey. However it would not be the right approach either to stimulate rural immigration hence decrease the population. Rural immigration is a reality of Turkey. There are no legal regulations that might blockade immigration and 
there should not be either. In that case a new approach that changes rural immigration reality into favorable effects for immigration reality should be adopted. As an outcome of decreasing population;

1. Agricultural lands and other enterprise entities abandoned by rural immigrants should be shared amongst the ones staying in rural lands -the close relatives in particular- and relevant legal regulations should be enacted. In that way fragmented, unorganized and small agricultural enterprises can be developed. Therefore these enterprises can turn into more economically advantageous companies.

2. With the development of leasing and partnership system, current agricultural lands shall be used by rural dwellers under appropriate conditions and public security. This shall also draw the attention of agricultural entrepreneurs not living in rural lands and increase the ratio of capital use in agriculture.

3. As an outcome of rural immigration, parallel to number of animals that might decrease the ratio of meadows and ranges per animal shall rise. Even better, with the improvement of animal races, it shall be possible to establish more productive and specialized husbandry holdings.

4. With the fall down in agricultural population alternative agricultural activities should be adopted and spread.

5. With the fall down in agricultural population the quantity and quality of agricultural subsidies can be enhanced and a better planning and organizational structure shall be formed in reaching these subsidies to appropriate places.

6. With the fall down in agricultural population, organizing in agriculture could be much simpler.

7. Fewer numbers of public personnel and resources shall be used thus public resources shall be employed more effectively.

\section{Conclusion and Suggestions}

Rural immigration is a significant economic and social phenomenon not only in Turkey but also in all developing countries. It is a necessity to clearly detect the causes and effects of this phenomenon. It would not be the right approach to claim that rural immigration process in Turkey has progressed parallel to industrialization and urbanization. The same process has taken place throughout a long period of time in Europe and followed the steps parallel to industrialization whereas in Turkey it has developed in quite a short length of time and with no specific plan. That should be considered as the primary reason why in Turkey rural immigration is regarded as a problem.

Rural immigration is a process that is completed in line with the plummet in rural population. The most effective source of population in rural lands is people who live off agriculture. Density in this population brings along additional agricultural problems as well as public costs. Instead of emphasizing the ways to stop rural immigration, new alternative activities that could be performed with the fewer rural population should be focused on. In line with the shrink in agricultural population density, new rural regulations should be enacted to seek solutions to agricultural problems- agriculture companies in particular. Thus, not only agricultural problems of the state shall be solved to a great extent but different problems of the country shall also be remedied to some degree.

\section{References}

[1]. Asfaha T.A, Jooste, A, 2006, "the Agricultural Input Elasticity of Rural-Urban Migration in South Africa," Agrekon, 45(1): 89-105.

[2]. Ayyıldız Tayyar, 1992, “Tarım Politikası Genel Politikalar ve Türkiye'de Durum', Erzurum: Atatürk Üniversitesi Yayınları No: 620: 283.

[3]. Baytal Yaşar, 2007, “Demokrat Parti Dönemi Ekonomi Politikaları (1950-1957)’,Ankara Üniversitesi Türk Inkklâp Tarihi Enstitüsü Atatürk Yolu Dergisi, Say1: 40: 545-567.

[4]. Başel Halis, 2012, 'The Causes of Population Mobility and Internal Migration in Turkey', http://www.iudergi.com/tr/index.php/sosyalsiyaset/article/ (04.01.2013).

[5]. Beauchemin Cris, Bocquier Philippe, 2003, 'Migration and Urbanization in Francophone West Africa: A review of the recent empirical evidence"'. Document de Travail,Dt/2003/09.

[6]. Bilsborrow Richard.E, 2002, “Migration, Population Change, and the Rural Environment', ECSP Report, Issue: 8: 69-94.

[7]. Bülbül Serpil, Köse Ali, 2010,"Türkiye'deBölgelerarasıİçGöçHareketlerininÇokBoyutluÖlçeklemeYöntemiileİncelenmesi', İstanbul Üniversitesi Işletme Fakültesi Dergisi, 39(1):.75-94

[8]. Çağlayan Savaş, 2006, “Göç Kuramları, Göç ve Göçmen İlişkisi’’, Muğla Üniversitesi Sosyal Bilimler EnstitüsüDergisi (İLKE), Say1: 17.

[9]. Çelik Fatih, 2006, 'İç Göçlerin İtici ve Çekici Güçler Yaklaşımı ile Analizi', Erciyes Üniversitesi İktisadi ve İdari Bilimler Fakültesi Dergisi, Sayı: 27:149-170.

[10]. Coşkun Ali, 2003, “Cumhuriyetin İlk Yıllarında TürkiyeEkonomisi”, Atatürkçü Düşünce Dergisi Sayı: 4: $72-77$.

[11]. Demirdöğen Alper, Ören M.Necat, Alemdar Tuna, 2012, Türkiye'de Tarım Politikaları Kapsamında Sağlanan Destekler ve Kırsal Yoksulluk, 10. Ulusal Tarım Ekonomisi Kongresi, 5-7 Eylül 2012, Konya, Türkiye.

[12]. Günaydın Gökhan, 2006, “ Türkiye'de Tarım Sektörü, ' Tarım ve Mühendislik', Sayı: 76-77:12-27.

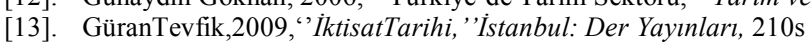

[14]. Gürbüz Mehmet, Karabulut Murat, 2008, 'Kırsal Göçler İle Sosyo-Ekonomik Özellikler Arasındaki İlişkilerin Analizi'’ TürkCoğrafyaDergisi, Sayı: 50, ss.37-60. 
[15]. Gürbüz Mehmet, 2007, “Yüreğir'e Göç Eden NüfusunSosyo-Ekonomik Özellikleri ve Şehirleşme Sürecindeki Değişimi”’ İstanbul Üniversitesi Edebiyat Fakültesi, Coğrafya Bölümü Dergisi, Sayı: 15:1-12.

[16]. Güreşci Ertuğrul, 2009, 'Kırsal Göç ve Tarım Politikası Arasındaki İlişki,'’Muğla Üniversitesi Sosyal Bilimler Enstitüsü Dergisi, Say1: 22: 51-67.

[17]. Güreşci Ertuğrul, AtsanTecer, 2009, “Avrupa Birliği’nin (AB) 2004 Yılı Genişleme Süreci Öncesinde Türkiye ve Diğer Aday Ülkelerin Ortak Tarım Politikası'na (OTP) Uyumları ve Karşılaştırılması,', Tarım Ekonomisi Dergisi, 15(2): 55-61.

[18]. Güreşci Ertuğrul, 2010, ‘Türkiye'de Kentten-KöyeGöçClgusu,’’DoğuşüniversitesiDergisi, 11(1): 77-86.

[19]. Güresci Ertuğrul, 2011, “'Türkiye’de Köyden Kente Göç ve Düşündürdükleri, ’ Sosyoekonomi, Özel Sayl: 201I- IM: 25-135.

[20]. Güreşci, Ertuğrul, 2012a, “Türkiye'nin Köyden Kente Göç Sorunu,', SGümüşhaneÜniversitesiSosyalBilimlerEnstüsüDergisi, Sayı: 6: 41-55.

[21]. Güresci Ertuğrul, 2012b, “Türkiye'de Kırsal Göçün Kırsal Bölge Ekonomileri Üzerine Olası Etkileri’, IV. Ulusal Yerel Ekonomiler Kongresi, 24-26 Mayıs, Gümüșhane.

[22]. Karagölge Cahit, Kızıloğlu Semiha, Yavuz Orhan, 2011, “Tarım Ekonomisi Temelïlkeleri,’Erzurum. Atatürk Üniv. Yayınları No: 801, Ziraat Fakültesi Yayınları No: 324, Ders KitaplarlSerisi: 73, 201 s,

[23]. Mendola Mariapia, 2006, "Rural out-Migration and Economic Development at Origin, What Do We Know, 'Sussex Migration Paper 40, University of Milano Bicocca and Cento Studi L. d'aglino.

[24]. Mere Francisco, 2007, "Rural Migration in Mexico,', 2007 Agricultural Outlook Forum Thursday, March 1, 2007.

[25]. Ofuoku Albert Ukaro, Chukwiji Christopher. Okeleke, 2012, 'the Impact of Rural-Urban Migration on Plantation Agriculturein the Niger Delta Region, Nigeria,'JJournal of Rural Social Sciences, 27(1): 137-151.

[26]. Olhan Emine, 2011, “Birleşmiş Milletler Ortak Programı 'Herkes İçin İnsanaYakışır İş: Ulusal Gençlik İstihdam Programıve Antalya Pilot Bölge Uygulaması'’Türkiye'deKırsalİstihdamınYapısı. MDG Achievement Fund, Türkiye İş Kurumu, 24s

[27]. Peker Kenan, 2004, 'The Causes and Results of Internal Migration from Rural Areas: Case of Eastern Anatolia',Agric. Econ. Czech, 50, 2004 (10): 471-476.

[28]. SağlamSerdar, 2006, “Türkiye'de İç Göç Olgusu veKentleşme,'’Hacettepe Üniversitesi Türkiyat Araştırmaları Enstitüsü, Say: 5: 3244.

[29]. ŞenelAlaeddin, 1982, “'̇lkel Topluluktan Uygar Topluma Geçiş Aşamasında Ekonomik Toplumsal Düşünsel Yapıların Etkileșimi”',Ankara Üniversitesi Siyasal Bilgiler FakültesiYayınlarl: 504, 324s.

[30]. Schmidbauer Harald, Rösch Angi, Erkol Narod, 2012, "A Leslie-type urban-rural migration model, and the situation of Germany and Turkey”. http://epc2012.princeton.edu/papers/121258, (03.01.2013).

[31]. Mevzuat., 2012,Köy Kanunu,http://www.mevzuat.adalet.gov.tr/html/368.html 04.01.2013).

[32]. T.C. Gıda, Tarım ve Hayvancılık Bakanlığı, 2011, AB Ortak Tarım Politikası ve Müzakere Süreci, 15s, Ankara.

[33]. T.C. Maliye Bakanlığı, 2011, Yillık Ekonomik Rapor, 138s, Ankara.

[34]. Taşçı Faruk, 2009, “Bir Sosyal Politika Sorunu Olarak Göç,', Kamu-İş, 10(4): 177-204.

[35]. TolunayAhmet, AkyolAyhan, 2006, "Kalkınma ve KirsalKalkınma: Temel Kavramlar ve Tanımlar,", Süleyman Demirel Üniversitesi Orman FakültesiDergisi Seri: A, Say1: 2: 121-132.

[36]. Topuz Hüseyin, 2007, “Cumhuriyet Dönemi Ekonomisinde Tarımsal Yapının İncelenmesi (1923-1950),Süleyman Demirel Üniversitesi İ.İ.B.F. 12(3): 367-380.

[37]. Toroğlu Emin, 2007, “Niğde İlinde GöçFaktörleriveGöçler,' CoğrafiBilimlerDergisi,5 (1): 75-96.

[38]. TÜIK, 2012a, Adrese Dayalı Nüfus Kayıt Sistemi Sonuçları, Ankara, Türkiye.

[39]. TÜİ, 2012b, Türkiye'nin Kır ve Kent NüfusuveOranları, Ankara, Türkiye.

[40]. Ucak Harun, Berk Ali, 2009, "Structural Change in Turkish Agricultural Insurance Policy and Recent Developments, 'WiadomościUbezpieczeniowe, 2/2009: 143-152.

[41]. Uysal Özlem Karahan, Oktay Erkan, 2008, Türkiye ve Avrupa Birliği Tarım Sektörlerinin Karşılaştırılması, 2. Ulusal İktisat Kongresi, 20-22 Şubat, İzmir.

[42]. Wikipedia, 2012, (http://tr.wikipedia.org/wiki/T\%C3\%BCrkiye demografisi, 03.01.2013).

[43]. Wosu, Eze, Anele A.Kinikanvo, 2010, "Rural-Urban Migration of Young Persons from Selected Conflict Ridden Communities in Rivers State: A Sociological Approach," AfricanJurnal of Political Science and International Relations, 4(6): $209-214$.

[44]. Yilmaz Hasan, 2006, 'Policies and Transition Problems of Agriculture in Turkey, 'Journal of Applied Sciences, 6(15): 3052-3059.

[45]. Zhang Kevin Honglin, Song Shungfeng, 2003, "Rural-urban migration and urbanization in China: Evidence from time-series and cross-section analyses, 'China Economic Review, 14 (2003): 386- 400. 